\title{
Training of Competency Test Modules Conducted in LSP-P1 Politeknik Negeri Bandung
}

\author{
Herawati Budiastuti ${ }^{1}$, Dhyna Analyes Trirahayu ${ }^{2}$, Tifa Paramitha ${ }^{3}$, Retno Indarti ${ }^{4}$, Emmanuela \\ Maria widyanti ${ }^{5}$, Ari Marlina ${ }^{6}$, Endang Widiyastuti ${ }^{7}$, Ismail Wellid ${ }^{8}$, \\ Chemical Engineering Department, Politeknik Negeri Bandung ${ }^{1,2,3,4,5,6,7}$ \\ Refrigeration and Air Conditioning Engineering Department, Politeknik Negeri Bandung ${ }^{8}$ \\ \{herabudi@polban.ac.id¹,dhyna.analyes@polban.ac.id²,tifa.paramitha@polban.ac.id³\}
}

\begin{abstract}
In the implementation of the level four of IQF (KKNI) held by the four Competency Test Places (TUK) owned by the First Party Professional Certification Body (LSP-P1) Politeknik Negeri Bandung (Polban) in 2019, there was a quite high gap, i.e. a number of participants were declared incompetent. The solution that can be overcome by the LSP-P1, is to provide more comprehensive theoretical and practical modules through training, before the competency test is conducted. This activity was carried out by TUK lecturers and assessors who had carried out the Indonesian Qualifications Framework (IQF) level four activities in 2019, with the participants from a Vocational High School in Bandung. The theoretical and practical modules delivered are in accordance with the Heat Exchanger Operation and Extraction Scheme and Spectophotometry UV/Vis and AAS and its Validation Scheme. This provision was conducted in the form of training with theoretical and practical modules contained in each scheme. The training has taken place from 26 July to 3 October 2020 for six times of meetings. Evaluation of the training was carried out by looking at the results of the theoretical and practical examinations as measured by an average score of at least 70 for every module.
\end{abstract}

Keywords: LSP-P1, Training, Modules, Competency Test

\section{Introduction}

In accordance with Permenristekdikti Number 26 year 2016, Recognition Prior Learning, hereinafter abbreviated as RPL, is an acknowledgment of a person's learning outcome obtained from formal or non-formal or informal education, and/or work experience in formal education. RPL aims to provide opportunities for people to enter the formal education system or be equivalent to certain qualifications based on formal, non-formal, informal education or work experience in very special or rare fields and are needed by the country such as lecturers, instructors, teachers, health professionals, and certain other very specific professions. Learning Outcomes (CP) mentioned above are abilities obtained through the internalization of knowledge, attitudes, skills, competencies and/or accumulated work experience.

In this case the RPL can be used to gain recognition of equality with certain qualifications according to the Indonesian Qualifications Framework (IQF/KKNI level B). Workers who 
have not received recognition can be facilitated by universities/politechnics to conduct individual assessments. For example to find out whether their learning or work experience has so far reached the same level as $\mathrm{CP}$ in certain study programs. To obtain recognition of equality with this qualification (RPL type B) can also be used for applicants who work in Vocational High Schools (SMK) as Vocational School Instructors or Vocational Madrasah Aliyah (MAK) instructors. This type B of RPL is to obtain equality with IQF (KKNI) Level 4 (Decree of the Director General of Learning \& Student Affairs No. 123 year 2017).

In this regard and in accordance with the government's wishes and programs for the development of quality human resources, it is carried out through the assurance of certain qualified educators and education personnel according to their educational background. The urgent matter is the availability of vocational instructor education personnel in accordance with Regulation of the minister of education and culture (Permendikbud) No. 34 year 2018, concerning National Standards for Vocational Secondary School Education and Vocational Madrasah Aliyah which are contained in Appendix V of Indonesian Educator and Education Standards.

Several Vocational High Schools in Bandung and its surroundings, have several instructors who work in laboratories with more than 5 (five) years of work experience. The educational qualifications of these instructors are still at the secondary school levels so that their educational qualifications need to be upgraded so that they are equivalent to the level 4 qualifications of the KKNI. Politeknik Negeri Bandung (Polban) as one of the Vocational Colleges in Bandung is obliged to meet the expectations of the Government and the expectations of human resources who are given the opportunity by the Government to obtain a more appropriate education in order to equalize their work experience which deserves to be respected as an equal. For this reason, in early 2019 Polban submitted a proposal to the Director General of Learning \& Student Affairs to obtain funding in order to participate in the equalization of secondary school level instructors into a higher level of educational recognition so that they can be equal to level 4 of KKNI.

The funding for level 4 of KKNI for secondary school level instructors has been successfully obtained and in September 2019 Polban had the opportunity to hold an RPL program for secondary school level graduates in order to support government programs to prepare instructors for secondary school level who competent in accordance with the demands of the business world and industry. Furthermore, the staffs with equal competence have obtained the qualifications of Vocational Instructors who meet the Educational Standards qualifications in accordance with Annex V Permendikbud No. 34 year 2018. The instructors of secondary school level who are declared competent are entitled to obtain a certificate/ recognition level 4 KKNI.

Polban has a First Party Professional Certification Body (LSP-P1) which has been licensed by the National Professional Certification Agency (BNSP) since 2018. So far, the LSP-P1 of Polban has overseen 4 (four) Competency Test Places (TUK) namely Chemical Engineering TUK, Analyst Chemistry TUK, Refrigeration Engineering TUK, and Civil Engineering TUK. Each TUK carries out their respective certification schemes according to the scope of their TUK. Each TUK has competency assessors who are also certified by BNSP. The level 4 KKNI equalization for secondary school level instructors was carried out in 4 TUKs owned by LSP-P1 Polban in 2019. The participation of Polban is one of the implementations of Presidential Instruction No. 9 year 2016 which regulates the revitalization of Vocational High Schools in the Context of Improving the Quality and Competitiveness of Indonesian Human Resources. 


\section{Methods}

The method of implementation of community service is shown in Figure 3.1. The steps of the community service activities in this figure can be described as follows:

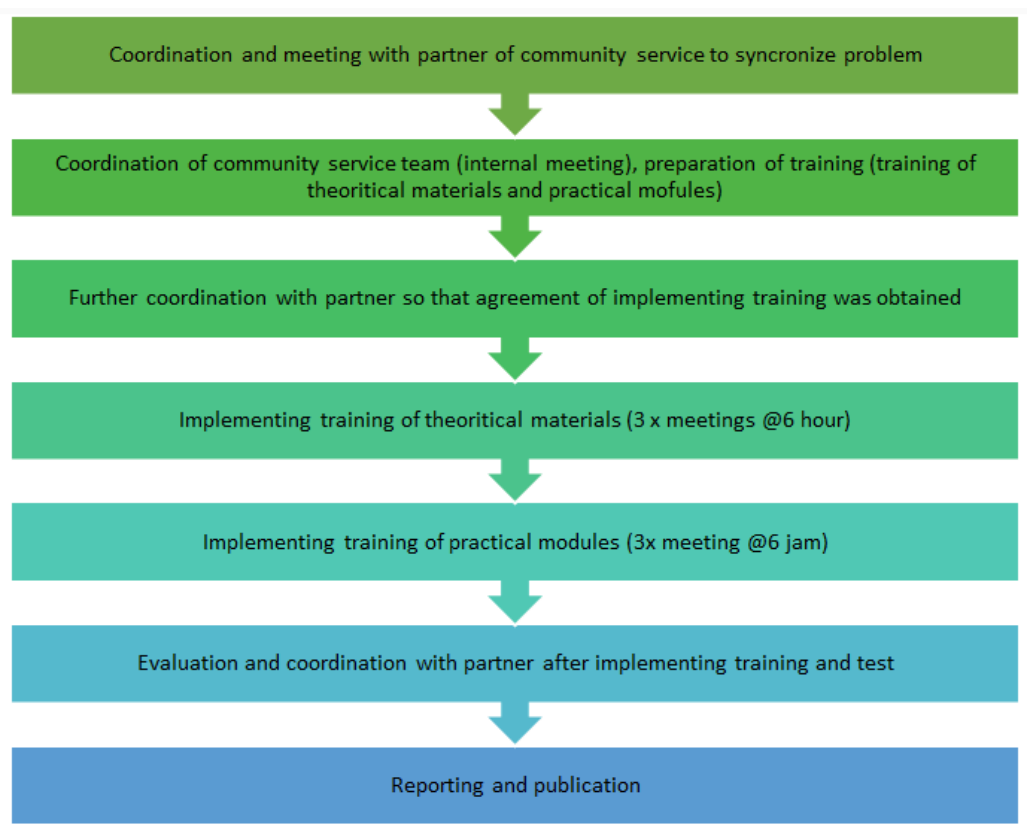

Fig. 1. Method of Implementation of Community Services

\section{a) Coordination and Meeting with Partners to Synchronize Problems}

Based on the implementation of the vocational instructor competency test that was carried out in 2019, there was a gap between competency test material and knowledge of assessment. The existence of this gap was coordinated with a Senior High School in Bandung as workplace of accession so that follow-up can be agreed upon this problem.

\section{b) Coordination of Community Service Team}

The results of coordination with this Senior High School were discussed in an internal meeting of the community service team, so that the steps to resolve this problem was obtained. The community service team consists of lecturers and assessors who are involved in equalization program of the secondary level Instructors in 2019. Thus, training of theoretical and practical modules were given in accordance with the material and modules of the competency test.

\section{c) Further Coordination with Partners}

The solutions that have been formulated by the community service team were coordinated with this Senior High School regarding the implementation schedule, materials, and other 
related matters so that community service activities can run well without significant obstacles due to the busy tasks of each participant as well as the lecturers and assessors.

\section{d) Preparation for Training}

The preparation process included compiling and printing the modules, purchasing practical materials (chemicals), training kits, and preparing the equipment used.

\section{e) Implementation of Training}

The training was carried out for 4 days consisting of teaching theoretical material and teaching practical modules (levelling 4 of KKNI).

\section{f) Test Activities}

Participants who have taken part in the training can participate the test. By implementing the test, it can be seen that participants really understand the training material, both theoretical and practical materials.

\section{g) Evaluation of the Implementation of Training and Tests}

The entire implementation of training and tests that have been carried out are then evaluated to determine their success.

\section{h) Further Coordination with Partner After Implementation of Program}

After all community service activities were carried out, further coordination was carried out with partner in order to obtain input from partners and follow-up cooperation.

\section{i) Reporting and Publication}

All community service activities that have been carried out were reported and published as the output of community service activities.

The description of the training can be explained in Table 1. as follows:

Participation of partner in program implementation is as training participants. Evaluation of implementation of program was carried out by observing the results of the theoretical and practical material tests so that the success of this activities was measured from the percentage of participants who managed to obtain an average score above 70 of each module.

Table 1. Description of Theoretical and Practical Trainings

\begin{tabular}{|c|c|c|c|}
\hline No & Training material & $\begin{array}{c}\text { Number of } \\
\text { hours }\end{array}$ & Aims \\
\hline \multicolumn{4}{|c|}{ Theoretical and Practical Modules } \\
\hline 1. & Work Safely & 4 hour & $\begin{array}{l}\text { Participants can understand the procedure } \\
\text { of work safely. }\end{array}$ \\
\hline 2. & Operate Fluid Flow Equipment & 6 hour & $\begin{array}{l}\text { Participants can understand the basic of } \\
\text { fluid flow tools. }\end{array}$ \\
\hline 3. & Operate Heat Exchanger & 6 hour & Participants can understand the basic of \\
\hline
\end{tabular}




\begin{tabular}{|c|c|c|c|}
\hline No & Training material & $\begin{array}{c}\text { Number of } \\
\text { hours }\end{array}$ & Aims \\
\hline \multicolumn{4}{|c|}{ Theoretical and Practical Modules } \\
\hline 4. & $\begin{array}{l}\text { Carry out a solid-liquid } \\
\text { extraction process }\end{array}$ & 6 hour & $\begin{array}{l}\text { Participants can understand the basic of } \\
\text { solid-liquid extraction tools. }\end{array}$ \\
\hline 5. & $\begin{array}{l}\text { Carry out a liquid-liquid } \\
\text { extraction process }\end{array}$ & 6 hour & $\begin{array}{l}\text { Participants can understand the basic of } \\
\text { solid-liquid extraction tools. }\end{array}$ \\
\hline 6. & $\begin{array}{l}\text { Validation of UV/Vis and } \\
\text { AAS spectrophotometric } \\
\text { test methods }\end{array}$ & 6 hour & $\begin{array}{l}\text { Participants can understand the basic of } \\
\text { U UV/Vis and AAS spectrophotometric test } \\
\text { tools as well as these validations. }\end{array}$ \\
\hline \multicolumn{4}{|c|}{ General Module } \\
\hline 1. & $\begin{array}{l}\text { Understanding TUK and } \\
\text { LSP-P1 Polban }\end{array}$ & 2 hour & $\begin{array}{l}\text { Participants can understand TUK and } \\
\text { LSP-P1 Polban }\end{array}$ \\
\hline
\end{tabular}

\section{Results and Discussion}

\subsection{Coordination with Partners and Internal Coordination of Community Service Team}

Implementation of community service was started from coordination between the chairperson and members of the community service and partner (a Secondary High School in Bandung) represented by the principal of this school. The community service team visited this school. The meeting was welcomed and approved by the implementation of community service activities. Even though the implementation of community service took the time of the participants (Instructors \& Teachers of this school), the principal allowed the implementation of this activities because it was considered very useful in increasing the knowledge and skills needed by Instructors \& Teachers of this school who had participated in the Competency Test at Polban in 2019. Coordination of community service and partner was held on June 2, 2020.

Table 2. Distribution of Tasks for Theoretical and Practical Training

\begin{tabular}{|c|c|c|c|}
\hline No & Training material & Amount of hours & Speaker \\
\hline \multicolumn{4}{|c|}{ Theoretical materials and practical modules } \\
\hline 1. & Work Safely & 4 hour & Tifa Paramitha \\
\hline 2. & Operate Fluid Flow Equipment & 6 hour & Dhyna Analyes Trirahayu \\
\hline 3. & Operate Heat Exchanger & 6 hour & Herawati Budiastuti \\
\hline 4. & Carry out a liquid-liquid extraction process & 6 hour & Emmanuela Maria Widyanti \\
\hline 5. & Carry out a solid-liquid extraction process & 6 hour & Retno Indarti \\
\hline 6 & $\begin{array}{l}\text { Validation of UV/Vis and AAS } \\
\text { spectrophotometric test methods }\end{array}$ & 6 hour & Ari Marlina \\
\hline \multicolumn{4}{|c|}{ General material } \\
\hline 1. & Understanding of TUK and LSP Polban & 2 hour & Ismail Wellid \\
\hline
\end{tabular}

After obtaining the approval and support from principal of this high school in Bandung, an internal coordination meeting was held by community service team and the community service experts. The community service team and the experts were the assessors of the previous competency test, so the implementation of existing activities was part of the implementation of assessor's duties in providing the accession. Coordination of community service team with partner was held on June 18, 2020. At this internal coordination meeting, tasks of each person were agreed to as shown in Table 2. 
In the implementation of the actual competency test, the assessors who are tasked with providing accession may not act as assessors during the competency test. In this community service, activities aimed to equip participants in terms of training to increase the knowledge and skills. At the end of the training, a competency test was not carried out but an examination of theoretical and practical modules provided during training was conducted. So this activity does not violate the rules set by LSP Polban and BNSP as the institution overseeing the competency test. If the competency test was conducted, the certificate will be in the form of a competency certificate submitted by the LSP to BNSP as the agency entitled to issue a competency certificate. In this community service, participants obtain training certificate issued by the LSP-P1 Polban.

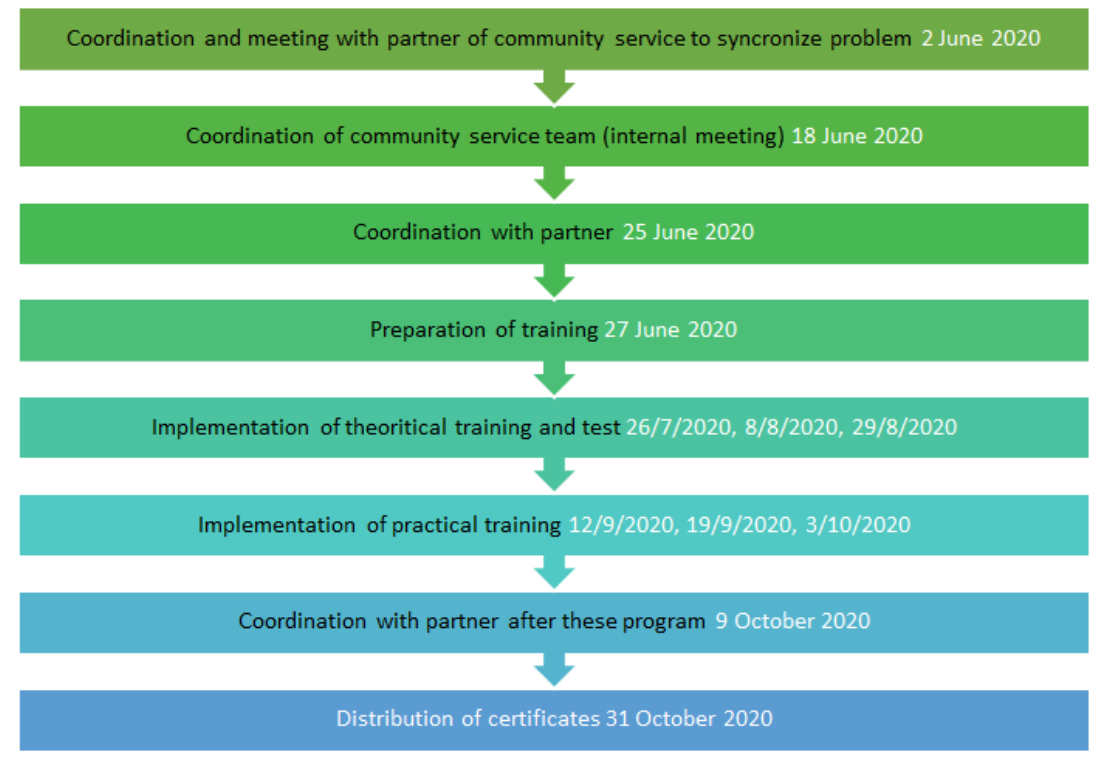

Fig. 2. Schedule of Community Service Activities

\subsection{Implementation of Theoretical Module Training}

The training was began with training of theoretical modules. This theoretical modules were the materials tested in TUK of Chemical Engineering and Analyst Chemistry. There is one scheme in these TUK. The heat exchanger and extraction operation scheme is a scheme that is supported by the TUK of Chemical Engineering. TUK of Analyst Chemistry provides a validation scheme for the UV/Vis and AAS spectrophotometry. The theoretical materials provided during the implementation of this community service were shown in Table 2 . The materials for the heat exchanger and extraction operation scheme include 5 theoretical modules, namely Work Safely, Operate Fluid Flow Equipment, Operate Heat Exchanger, Carry out a Liquid-Liquid Extraction Process, and Carry out a Solid-Liquid Extraction Process. The materials of Validation of the UV/Vis and AAS spectrophotometry scheme include UV/Vis and AAS Spectrophotometry material as well as test method material.

With detailed explanations of each material by experts, an understanding of the theoretical background of each module was obtained in accordance with the desired theoretical understanding when competency tests are carried out for each module in these two schemes. 
Before implementing the theoretical material in the two schemes, the understanding of TUK and LSP-P1 in Polban was explained. This explanation was carried out in order to provide a clear information of the meaning of TUK and LSP and at the same time provide knowledge about two other TUK which had been managed by LSP-P1 Polban. The two TUK are TUK of Civil Engineering and TUK of Refrigeration and Air Conditioning Engineering.

The schedule for the implementation of training of theoretical modules was held on July 26, 2020, August 8, 2020, and August 29, 2020 as shown in Figure 2. The students assisted in the implementation of this training of theoretical materials. The test results before and after the explanation of theoretical materials are presented in Figure 3.

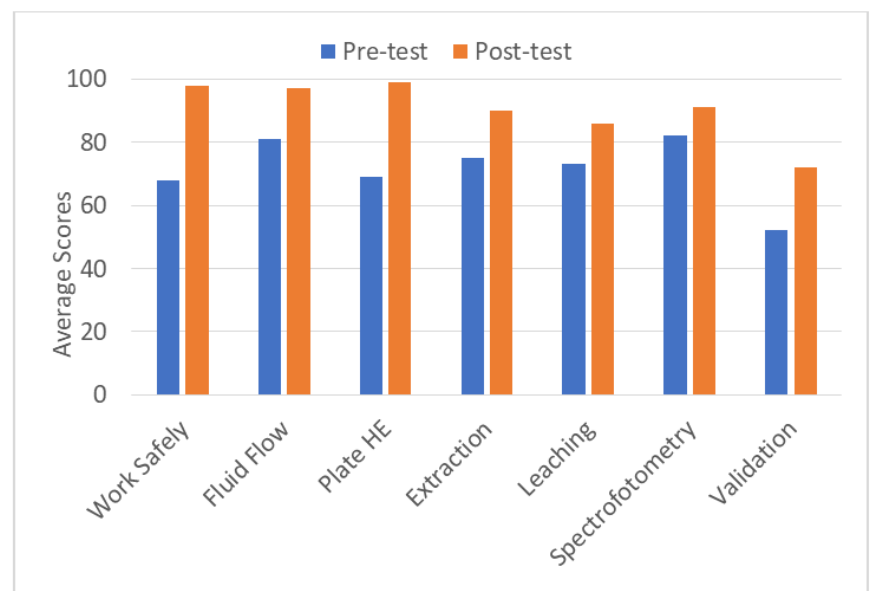

Fig. 3. Pre and Post Tests Results for Theoretical Modules

\subsection{Implementation of Practical Module Training}

The training for practical modules was carried out on September 12, 2020, September 19, 2020, and October 3, 2020 as shown in Figure 2. The practical modules were presented through a video that has been prepared. Practical demonstration was carried out by the experts with the help of their students which was carried out onsite at the Chemical Engineering Laboratory, Pilot Pant Laboratory, and the Instrument Analytical Laboratory. With detailed demonstrations and video explanations for each module by the experts, an understanding of the operation of each module was obtained as desired when the competency test of each of these schemes was carried out.

\section{Conclusion and Suggestion}

In the implementation of equalization of level 4 KKNI by the four TUKs owned by the LSP-P1 Polban, there is a fairly high gap. This gap can be seen from the results of equalization of level 4 KKNI where a number of participants were declared not competent. From the results of interviews and evaluations after the program has been completed, it was found that several obstacles/problems can be overcome by participants and by LSP as the organizer of education equalization of level $4 \mathrm{KKNI}$. The solution of this problem was proposed as community service activities carried out by lecturers and assessors who have carried out 
equalization of level 4 KKNI in 2019. The main solution intended are theoretical modules training related to theoretical knowledge which was recognized based on the work experience of the participants and practical modules training related to the implementation of competency tests for participants. The theoretical training, pre-test and post-test were held on July 26, August 8, and August 29, 2020. The training of practical module was carried out on September 12, September 19, and October 3, 2020 .

The two forms of training that have been carried out are not only beneficial for the partner but also beneficial for Polban, especially in holding equal education levels for other participants in general. For this reason, it was suggested that cooperation with the partner can be continued and can also be developed for cooperation in other fields. Polban as a vocational tertiary institution should be closely related to Vocational High School where these students are one of the targets for new students in Polban.

\section{Acknowledgements}

Acknowledgments were conveyed to the Center of Research and Comunity Services, Politeknik Negeri Bandung for research funding in accordance with Research Implementation Agreement Letter No. B/187.24/PL1.R7/PM.01.01/2020.

\section{References}

[1] Permenristek dikti No. 26 year 2016, Recognition of Prior Learning, https://kemdikbud.go.id/main/files/download/e451d9ec3a04121

[2] Decree of the Director General of Learning and Student Affairs Number 123/B/SK/2017, Guidelines for Conducting Recognition of Prior Learning, https://belmawa.ristekdikti.go.id/wp-content/uploads/2017/04/Lampiran-PedomanRPL-SALINAN.pdf

[3] Regulation of the Minister of Education and Culture of the Republic of Indonesia No. 34 year 2018, National Vocational High School Education Standards/Vocational Madrasah Aliyah, https://jdih.kemdikbud.go.id/arsip/Permendikbud\%20Nomor\%2034\%20Tahun\%20 2018.pdf

[4] Instruction of President No. 9 year 2016, Revitalization of Vocational High Schools in the Context of Improving the Quality and Competitiveness of Indonesian Human Resources, https://kemdikbud.go.id/main/files/download/e451d9ec3a04121 